\title{
Guide to the Bibliography
}

\begin{abstract}
SCOPE
This bibliography primarily consists of books and pamphlets on grapes, wines, other alcoholic beverages, and the temperance and prohibition movements, published in this country. The majority of the entries concern wine, but other alcoholic beverages such as distilled spirits, beer, and cider are included, since these were and continue to be of major interest to consumers and scholars. Temperance and prohibition items are covered as well because they document the early interest in overconsumption of alcoholic beverages and the consequent social problems. All bibliographers face the problem of what to exclude. In most cases we have erred on the side of leniency and included works if we felt that the intended users of the bibliography could benefit.

From bibliographic records, catalogs, and bibliographies, it is frequently difficult to distinguish items that were published as part of a larger work (e.g., as an article in a journal or as a chapter in a book) from those that were separately published and therefore monographic in nature. Often a journal article was simultaneously printed or later reprinted as a separate publication, with or without different pagination. The Library of Congress and the Library of the U.S. Department of Agriculture have cataloged articles from early Patent Office reports as if they were separate publications, and in fact some probably were. The California Board of State Viticultural Commissioners often reprinted parts of its reports as separate publications. To provide as much access as possible, we have included individual articles that appeared in the reports and transactions of the various state agricultural and horticultural societies even if they have not appeared as separate publications. These articles provide an interesting profile of the information available to the local grape grower and wine maker.

The monographic entries relating to wine and grapes are fairly comprehensive. The entries describing publications of the federal and state governments and of state experiment stations are likewise comprehensive. But more work is needed in several areas. Nursery catalogs in several major collections and many minor collections warrant further study. Of particular interest are the many catalogs of smaller nurseries that list varieties and therefore provide a firsthand account of varieties available by region and within specific time periods. California nursery catalogs are well covered by Brown (1989), but the same degree of coverage is lacking for other states. Entries for the many state horticultural and agricultural societies need additional effort because the collections available to us were incomplete. The remaining area that could be studied further is temperance, given the numerous arguments for and against alcohol or its temperate use.

We have also barely entered the labyrinth of state and city legislation concerning the sale of alcoholic beverages. However, our work on federal laws and regulations concerning production and taxation of alcoholic beverages is nearly complete, although we have not been able to identify all wine-specific publications. Much legal material was not separately published and for this reason is seldom listed in catalogs and bibliographies.
\end{abstract}

\section{EXPLANATION OF ENTRIES}

The entries are arranged in alphabetic order by first author or corporate author. Lacking an author, the entries are filed by the title, with authors and titles inter-filed alphabetically. Following the author's name are the author's birth and death years, if available. The next item is the title. Where the title ends in an ellipse, one of two things has occurred: either the 


\section{Guide to the Bibliography}

omitted information is a statement of responsibility (e.g., by John Doe) or the title is very lengthy and only the most important part has been included. Following the title is the imprint: place of publication, publisher, and date of publication. Next is the physical description: number of pages, noteworthy information (e.g., presence of illustrations, frontispieces, etc.), and height of spine. In many cases this physical description is lacking in the cataloging records available to us and so is omitted here unless we were able to locate a copy and measure the spine or count the pages. Next is information of general interest such as, in the case of nursery catalogs, the number of grape varieties included.

The final part of the entry gives the item's location. This location information can include either specific libraries or standard bibliographies or both. The absence of such information indicates that the item can be found in the National Union Catalog Pre-1956 Imprints. Gabler (1985) has been checked thoroughly and the Gabler numbers included in this bibliography. Where numbers from such standard bibliographies as Shoemaker (1964-1972) appeared in the cataloging, that information is supplied. A full bibliographic entry for each of these sources is included in the References section of this work.

Additional information also appears in some entries. In some cases extensive notes further illuminate the subject or the source of the item (e.g., California Board of State Viticultural Commissioners). "Ghost" denotes an item that probably does not exist. (Ghost bibliographic entries are an informal tradition of bibliography and were presumably created when bored bibliographers and catalogers made up fictitious entries to amuse themselves.) A crossreferenced item included in this bibliography is indicated by "q.v." Gaps in the numbering of entries were intentionally left for future expansion or occurred when items were dropped. Where expansion was needed but the numbering would not accommodate it, a decimal has been used (e.g., 1000.1). Information in brackets was found outside of the title page or verso of the title page.

\section{LANGUAGES REPRESENTED IN THE BIBLIOGRAPHY}

While primarily containing English language material, this bibliography also includes a significant number of titles published in German, with German language titles on wine published before 1901 in the United States far outnumbering those in French, the other foreign language represented. Also of interest is that several English language titles of this period were translated into German, French, and Italian. The bibliography includes, as would be expected, a large number of titles originally issued in German, French, Italian, Spanish, and Portuguese, and translated into English and published in the United States.

\section{GABLER NUMBERS AND OTHER SOURCES}

As part of the citations, reference is made to the other similar bibliography in this field, Wine into Words: A History and Bibliography of Wine Books in the English Language by James M. Gabler. A Gabler number indicates that the entry is also in Gabler's bibliography. In addition, other such numbers that appeared in the cataloging and bibliographic records used to compile this bibliography have also been included (e.g., Shoemaker 1964-1972). The absence of such a number, however, does not imply that the work is not to be found in those sources. Only Gabler's bibliography has been checked completely. Wherever possible, if the item is not included in the National Union Catalog Pre-1956 $\left(\mathrm{NUC}^{\circ}\right)$, the entry notes in what source the item was found.

\section{MEASUREMENTS}

Where possible, the spine height is listed in centimeters and was for the most part taken from existing cataloging. In some cases where cataloging omitted spine height, we were able to 


\section{Guide to the Bibliography}

examine the volume and measure the spine and supply the missing information. When available cataloging gave the spine height in more archaic terms such as quarto (4to), octavo (8vo), or duodecimo ( $12 \mathrm{mo}$ ), we included the information in that form since it represents a range of measurement rather than an exact centimeter measurement. (For more information, see "book sizes" in Peters 1983.) If the cataloging lacked size information and we were unable to examine the item, no measurement appears in the entry.

\section{ABBREVIATIONS AND CODES}

NUC refers to the National Union Catalog: Pre-1956 Imprints.

$\mathrm{NUC}^{\circ}$ denotes that the item is not listed in the NUC. Where possible, the location of items not in the NUC is given using the standardized NUC library codes. Transactions of state agricultural societies and other similar organizations are not as a rule included in the NUC because they are for the most part considered serials. These publications are widely available in Land Grant institution libraries.

The NUC codes used in this bibliography are:

\begin{tabular}{|c|c|}
\hline C & $\begin{array}{l}\text { California State Library, } \\
\text { Sacramento }\end{array}$ \\
\hline $\mathrm{CHi}$ & California Historical Society \\
\hline CChiS & California State University, Chico \\
\hline CFS & California State University, Fresno \\
\hline CLU & $\begin{array}{l}\text { University of California, Los } \\
\text { Angeles }\end{array}$ \\
\hline CSfCP & Society of California Pioneers \\
\hline $\mathrm{CsmH}$ & Henry E. Huntington Library \\
\hline $\mathrm{CU}$ & University of California, Berkeley \\
\hline CU-A & University of California, Davis \\
\hline CU-B & $\begin{array}{l}\text { Bancroft Library, University of } \\
\text { California, Berkeley }\end{array}$ \\
\hline DLC & Library of Congress \\
\hline DNAL & National Agricultural Library \\
\hline DNLM & National Library of Medicine \\
\hline GU & University of Georgia \\
\hline IC & Chicago Public Library \\
\hline ICJ & John Crerar Library \\
\hline MBH & $\begin{array}{l}\text { Massachusetts Horticultural } \\
\text { Society }\end{array}$ \\
\hline MH & Harvard University \\
\hline $\mathrm{MH}-\mathrm{A}$ & $\begin{array}{l}\text { Arnold Arboretum, Harvard } \\
\text { University }\end{array}$ \\
\hline
\end{tabular}

\begin{tabular}{|c|c|}
\hline MH-BA & $\begin{array}{l}\text { Graduate School of Business, } \\
\text { Harvard University }\end{array}$ \\
\hline MiEM & Michigan State University \\
\hline $\mathrm{MiU}$ & University of Michigan \\
\hline $\mathrm{N}$ & New York State Library \\
\hline $\mathrm{NeU}$ & University of North Carolina \\
\hline NhD & Dartmouth College \\
\hline NNNAM & New York Academy of Medicine \\
\hline NIC & $\begin{array}{l}\text { Cornell University Library, New } \\
\text { York }\end{array}$ \\
\hline $\mathrm{NN}$ & New York Public Library \\
\hline OKentC & Kent State University Library, Ohio \\
\hline PKsL & $\begin{array}{l}\text { Longwood Gardens, Kennett } \\
\text { Square, Pernsylvania }\end{array}$ \\
\hline PPAN & $\begin{array}{l}\text { Academy of Natural Sciences, } \\
\text { Philadelphia }\end{array}$ \\
\hline PPG & German Society of Pennsylvania \\
\hline PPHi & Historical Society of Pennsylvania \\
\hline PPPrHi & $\begin{array}{l}\text { Presbyterian Historical Society, } \\
\text { Philadelphia }\end{array}$ \\
\hline PPULC & $\begin{array}{l}\text { Union Library Catalogue of } \\
\text { Pennsylvania, Philadelphia }\end{array}$ \\
\hline
\end{tabular}

Libraries without NUC codes are:

Alfred Fromm Rare Wine Books Library

This collection was a part of the Wine Museum of San Francisco and the Christian Brothers Collection until it was donated to The Seagram Museum in Waterloo, Ontario, in 1984.

Barton's Distillery Museum, Bardstown Kentucky 